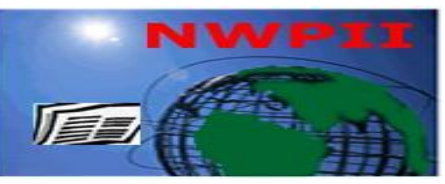

American Journal of Biomedical Sciences

ISSN: 1937-9080

nwpii.com/ajbms

\title{
Comparative Antidiarrheal Activity of Three Bangladeshi Medicinal Plants Using in Vivo Animal Model Study
}

\author{
Rashaduz Zaman ${ }^{1 *}$, Mohammad Parvez ${ }^{1}$, Md. Imran Hasan ${ }^{1}$, Md. Sekenedar Ali ${ }^{1}$, \\ Mohammed Abu Sayeed ${ }^{1}$, Md. Aslam Hossain ${ }^{2}$
}

${ }^{1}$ Department of Pharmacy Faculty of Science and Engineering, International Islamic University Chittagong, Chittagong-4203, Bangladesh.

${ }^{2}$ Department of Pharmaceutical Chemistry, Faculty of Pharmacy, University of Dhaka. Dhaka- 1000, Bangladesh.

"Corresponding Author

Rashaduz Zaman

Department of Pharmacy

International Islamic University Chittagong

Chittagong-4203

Bangladesh

Cell: +8801822323331

Email: rashad.pharma.iiuc@gmail.com

Received: 14 July 2015; | Revised: 16 December 2015; | Accepted: 20 December 2015

\begin{abstract}
Diarrhea is a worldwide concern. So this study investigated the antidiarrheal effect of methanol extract of leaves of Podocarpus neriifolius D. Don., Mangifera sylvatica Roxb. and Ficus sagittata Vhal. using in vivo animal model. These plants have history of ethnobotanical use. Antidiarrheal effect was assessed in Castor oil induced diarrheal test model in Swiss Albino mice. Lopramide $(5 \mathrm{mg} / \mathrm{kg}$ ) was used as standard drug. The animals were treated with doses of 200 and $400 \mathrm{mg} / \mathrm{kg}$ of the plant extracts. All data were analyzed by the software, statistical package for social science (SPSS), Version 18.0. The extracts (200 and $400 \mathrm{mg} / \mathrm{kg}$ ) showed a remarkable antidiarrheal activity by reducing the number of defecation and maintaining the consistency of faeces. All the extracts significantly $(P<0.001)$ inhibited the diarrheal incidence at the dose of 200 and $400 \mathrm{mg} / \mathrm{kg}$. Mangifera sylvatica showed the highest percent of inhibition of $72.37 \%$ at dose of $400 \mathrm{mg} / \mathrm{kg}$ and Ficus sagittata showed the lowest (52.63\%) percent of inhibition at dose of $200 \mathrm{mg} / \mathrm{kg}$ while the standard Loperamide showed $77.63 \%$ of diarrheal inhibition. The results suggest the potentiality of Podocarpus neriifolius, Mangifera sylvatica and Ficus sagittata as antidiarrheal drugs but further investigations are required to find out the exact mechanism of action and the chemicals responsible for the effect.
\end{abstract}

Keywords: Antidiarrheal, Castor-oil, Podocarpus neriifolius, Ficus sagittata, Mangifera sylvatica, Loperamide. 


\section{Introduction}

Diarrheal diseases are a major problem in third world countries and are responsible for the death of millions of people each year [1]. Every year, more than 5-8 million deaths are infant and children under 5 years [2]. The curve of diarrheal patient increases gradually day by day [3]. World health organization (WHO) reports that about $80 \%$ of people used plants as traditional medicine [4]. Medicinal plants are a promising source of antidiarrheal drugs [5]. For this reason, international organizations including the World Health Organization (WHO) have encouraged studies pertaining to the treatment and prevention of diarrheal diseases using traditional medical practices [6,7,8]. FDA has also approved the botanical drug, Fulyzac, as the first antidiarrheal drug for the HIV/ (AIDS) patients [9].

Podocarpus neriifolius D. Don is a medium to large sized tree; reach up to $35-45 \mathrm{~m}$ tall. Its bole is columnar, branchless, around $22 \mathrm{~cm}$ and up to $100 \mathrm{~cm}$ in diameter. The surface of bark is grayish-brown. The foliage buds are ovate, acute or blunt and often with spreading scales. It is the most widespread species of genus, occurring from Nepal, India, Indo-China and Thailand, throughout Malaysia, towards the Solomon Island and Fiji [10,11] Eleven compositions isolated from Podocarpus neriifolius D. Don were identified as $n-\mathrm{C}_{34} \mathrm{H}_{69} \mathrm{OH}, \beta$-sitosteryl stearate, $\beta$ sitosterol, sciadopitysin, podocarpusflavone $\mathrm{B}$, robustaflavone-7"-methyl ether, podocarpusflavone A, robustaflavone, p-hydroxyl benzoic acid, 2"-O-rhamnosylscopariu, 2"-Orhamnosyl vitexin on the basis of physical constants and spectral data [12]. Podocarpus neriifolius is reported to have antiproliferative [13], cytotoxic and thrombolytic activities. Leaves have been reported to be used as boiled water for bathing. Bark decoction is applied with cotton on herpes [14].

Mangifera sylvatica Roxb. is a plant in the 'Anacardiaceae' family. It is found in Bangladesh, Cambodia, China, India, Myanmar, Nepal, and Thailand. The fruit is obliquely ovate, $8-10 \mathrm{~cm}$ long; much compressed distally forming a hook and has scantly whitish-yellow pulp which is almost fibreless. It is reported to have alkaloids, carbohydrates, proteins, cardiac glycosides, steroid, phenols, tannins, saponins, flavonoids, terpenoids and thrombolytic activity [16].

Ficus sagittata vhal (Family: Moraceae) is a climbing shrub when young, often starting life as an epiphyte. As it grows older it can become a tree. The plant is sometimes harvested from the wild for local medicinal use. It is cultivated for its ornamental value. It is common in lowland to montane forest, at elevations up to 1,600 meters. The plant is distributed throughout the world primarily in subtropical and tropical regions. It is distributed in India (Andaman Islands, Assam, Meghalaya, Sikkim), Bhutan, China, Bangladesh, Myanmar, Indochina, Malaysia [16].

In this study, we intended to investigate the anti-diarrheal activity of methanol extract of three medicinal plants leaves.

\section{Materials and Methods}

\subsection{Plant material collection}

Samples of the plants were collected from local area of Chittagong University in the month of August, 2014 and identified by an expert of botany and plant Herbarium specialist Dr. Shaikh Bokhtear Uddin, Associate professor, Department of Botany, University of Chittagong. The collected plant leaves were shade dried for twenty days in the low temperature and pulverized into a coarse powder using a suitable grinder (NOWAKE, Japan). The powder was stored in an airtight container and kept in a cool, dark, and dry place until further analysis.

\subsection{Extraction Process}

Approximately $650 \mathrm{gm}$ powdered material was placed in clean flat bottomed glass container and soaked in 1.5 liter methanol. The container with its content was sealed and kept for 15 days accompanied with occasional shaking and stirring for maximum wetting and extraction. The entire mixture was coarse filtration by piece of clean white muslin cloth. Then the extract was filtered through Whatman filter paper (Bibby RE200, Sterilin Ltd., UK) and was concentrated to obtain methanol crude extract and evaporated to dry using water bath. Then the extract was stored at $4^{\circ} \mathrm{C}$ until used. 


\subsection{Chemicals and reagents}

Methanol (99\%) was purchased from SigmaAldrich (India) through the vendor Taj Scientific (Anderkilla, Chittagong, Bangladesh). Loperamide was collected from Square pharmaceuticals Ltd., Bangladesh. Castor oil (WELL's Heath Care, Spain) and Tween 80 (Lab grade) were also used in the experiment.

\subsection{Animals used in the experiments}

Swiss albino mice (both sexes) weighing between (18-25 g) was used for the present study collected from International Centre for Diarrheal Diseases and Research, Bangladesh (ICDDR, B), Dhaka, Bangladesh. After their purchase, the mice's were kept in standard environmental conditions $\left(24.0 \pm 0^{\circ} \mathrm{C} \& 55-65 \%\right.$ relative humidity and $12 \mathrm{~h}$ light/dark cycle) for one week to acclimate and fed ICDDRB formulated rodent food and water ad libitum. All experiments involving animals were conducted according to the UK Home Office regulations (UK Animals Scientific Procedures Act 1986) and the 'Principles of Laboratory Animal Care' (National Institutes of Health publication no. 86-23, revised 1985).

\subsection{Acute toxicity test}

The acute toxicity of methanol extract of Podocarpus neriifolius (MEPN), Mangifera sylvatica (MEMS) and Ficus sagittata (MEFS) were determined as per the OECD guideline no. 423 (Acute Toxic Class Method). It was observed that the test extracts were not lethal to the mice even at $2000 \mathrm{mg} / \mathrm{kg}$ dose. Hence, $1 / 5$ th $(400 \mathrm{mg} / \mathrm{kg})$ and $1 / 10 \mathrm{th}(200 \mathrm{mg} / \mathrm{kg})$ of doses were selected for further study [17].

\subsection{Antidiarrheal activity test}

The antidiarrheal effects of plants extracts were evaluated according to the method described by Shoba and Thomas [26] with minor modifications. In vivo animal model was used in the experiment. Mice were fasted for $24 \mathrm{~h}$ and were divided into Eight groups $(\mathrm{n}=5)$. Group I received $10 \mathrm{~mL} / \mathrm{kg}$ of Tween $80(1 \%$ Tween 80 in water) orally and served as control animals. Animals in group II received loperamide (5 $\mathrm{mg} / \mathrm{kg}$, p.o.) and served as the standard treatment group, whereas groups III and IV received orally 200 and $400 \mathrm{mg} / \mathrm{kg}$ of methanol extract of Podocarpus neriifolius respectively. Groups V and VI received orally 200 and 400 $\mathrm{mg} / \mathrm{kg}$ of methanol extract of Mangifera sylvatica respectively. Groups VII and VIII received orally 200 and $400 \mathrm{mg} / \mathrm{kg}$ of methanolic extract of Ficus sagittata respectively. The extract was suspended in Tween $80(1 \% \mathrm{v} / \mathrm{v})$. One hour after oral administration of treatments, the animals received castor oil $1 \mathrm{~mL}$ orally, and they were individually placed in boxes, the floor of which lined with blotting paper for observation of the number and consistency of faecal droppings. The numbers of both wet and dry droppings were counted every $60 \mathrm{~min}$ for $4 \mathrm{~h}$, and the white paper was changed after each evaluation. The means of the stools passed by the treated groups were compared with that of the control group. The mean number of diarrheic faeces pooled by the control group was considered as $100 \%$. The stools passed by the treated groups that's compared with the control and standard. During an observation period of 4 hours, the total number of faeces which were excreted by the animals was recorded. The level of inhibition (\%) of defecation caused by extracts was calculated relative to the control using the following relationship:

\section{Inhibition of defecation $(\%)=[(\mathrm{NDC}$ - NDT)/NDC] × 100;}

Where, NDC $=$ mean number of diarrheic faeces of the control group;

NDT = mean number of diarrheic faeces of the treated group.

Total weight of both dry and wet faeces in each group was taken after every hour. It was recorded for total of 4 hours. The weight of the stools was plotted against the hours for each group and evaluated the curves for diarrheal stool secretion after each hour.

\subsection{Statistical analysis}

The results of the experiments were analyzed by one-way ANOVA followed by Dunnett's test using SPSS Data Editor for Windows, Version 
18.0 (SPSS Inc., U.S.A.). Values are represented as mean \pm S.E.M. Significant value was set at $P<0.001$

\section{Results}

In the castor oil-induced diarrhea experiment, the leaves extract of Mangifera sylvatica produced a marked antidiarrheal effect in the mice, as shown in Table 1. At doses of 200 and $400 \mathrm{mg} / \mathrm{kg}$, the extract produced significant $(\mathrm{P}<$ $0.001)$ defecation. The total number of wet feces produced upon administration of castor oil decreased in all of the treated extracts compared to the control group $(15.2 \pm 0.80)$ while loperamide decreased to $3.4 \pm 0.51$ at the dose of 5 $\mathrm{mg} / \mathrm{kg}$. The highest percent of diarrheal inhibition was at $400 \mathrm{mg} / \mathrm{kg}$ of methanol extract of Mangifera sylvatica which produced $72.37 \%$ inhibition and that the standard Lopermaide produced $77.63 \%$ inhibition. The lowest diarrheal inhibition was at $200 \mathrm{mg} / \mathrm{kg}$ of methnol extract of Ficus sagittata which produced $52.63 \%$ inhibition.

Table 1: Effect of methanol extracts of three plants on Castor oil induced diarrhea in mice.

\begin{tabular}{|c|c|c|c|c|c|c|}
\hline Groups & Treatment & Dose & $\begin{array}{l}\text { Total number } \\
\text { of feces }\end{array}$ & $\begin{array}{l}\% \text { inhibition } \\
\text { of defecation }\end{array}$ & $\begin{array}{l}\text { Total } \\
\text { number of } \\
\text { diarrheal } \\
\text { feces }\end{array}$ & $\begin{array}{l}\% \\
\text { inhibition } \\
\text { of diarrhea }\end{array}$ \\
\hline $\mathrm{I}$ & $\begin{array}{l}\text { Castor oil+ Tween } \\
80 \text { solution }\end{array}$ & $10 \mathrm{~mL} / \mathrm{kg}$ & $17.4 \pm 1.1$ & - & $15.2 \pm 0.80$ & - \\
\hline II & $\begin{array}{l}\text { Castor oil+ } \\
\text { Loperamide }\end{array}$ & $5 \mathrm{mg} / \mathrm{kg}$ & $5.8 \pm 0.58 *$ & 66.67 & $3.4 \pm 0.51 *$ & 77.63 \\
\hline III & Castor oil+ MEPN & $200 \mathrm{mg} / \mathrm{kg}$ & $10 \pm 1.0 *$ & 42.53 & $6.4 \pm 0.51 *$ & 57.89 \\
\hline IV & Castor oil+ MEPN & $400 \mathrm{mg} / \mathrm{kg}$ & $8.4 \pm 1.0 *$ & 51.72 & $5.4 \pm 0.40 *$ & 64.43 \\
\hline $\mathrm{V}$ & Castor oil+ MEMS & $200 \mathrm{mg} / \mathrm{kg}$ & $9.6 \pm 1.1 *$ & 44.83 & $5.8 \pm 0.58^{*}$ & 61.84 \\
\hline VI & Castor oil+ MEMS & $400 \mathrm{mg} / \mathrm{kg}$ & $7 \pm 0.55^{*}$ & 59.77 & $4.2 \pm 0.66^{*}$ & 72.37 \\
\hline VII & Castor oil+ MEFS & $200 \mathrm{mg} / \mathrm{kg}$ & $11.2 \pm 0.86$ & 35.63 & $7.2 \pm 0.66^{*}$ & 52.63 \\
\hline VIII & Castor oil+ MEFS & $400 \mathrm{mg} / \mathrm{kg}$ & $9.4 \pm 0.93 *$ & 45.98 & $5.6 \pm 0.40 *$ & 63.16 \\
\hline
\end{tabular}

MEPN= Methanol extract of Podocarpus neriifolius; MEMS= Methanol extract of Mangifera sylvatica; MEFS= Methanol extract of Ficus sagittata; Values represented as Mean \pm S.E.M. of 5 mice in each group; Statistical analysis was done by One-way ANOVA followed by Dunnett's test (against control). *Significant at $P<0.0001$. 
There has been a wide variation in the weight of the total stool amongst the different groups which was counted after each hour (Figure 1).
Weight of the stools decreased simultaneously in all the groups in the similar manner.

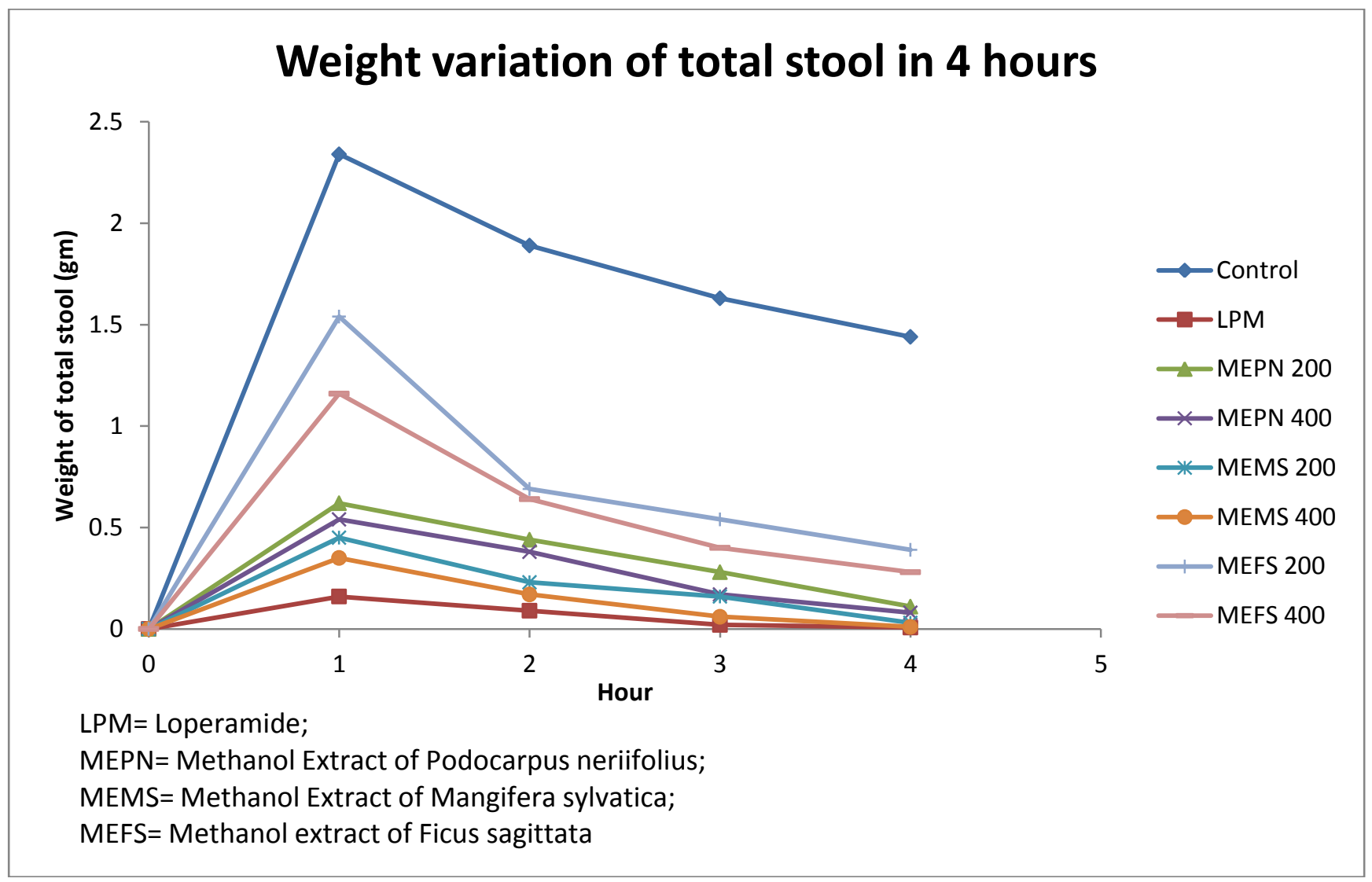

Figure 1: Weight variation of total stool in 4 hours in different extracts treated, standard and control mice.

\section{Discussion}

From the study of these experiments, we found that all of the three evaluated plant extract showed antidiarrheal activity in different extent in comparison with the standard Loperamide (5 $\mathrm{mg} / \mathrm{kg}$ ). Methanol extract of Mangifera sylvatica showed the highest percent of diarrheal inhibition while the methanol extract of Ficus sagittata showed the lowest percent of diarrheal inhibition. Methanol extract of Podocarpus neriifolius $(57.89 \%$ at $200 \mathrm{mg} / \mathrm{kg}$ and $64.43 \%$ at $400 \mathrm{mg} / \mathrm{kg}$ ) showed results close to that of Mangifera sylvatica.

Usually diarrhea is considered as a consequence of altered motility and fluid accumulation in intestinal tract. Diarrhea can be induced by castor oil through the production of active metabolite ricinolic acid [18]. Ricinolic acid increases peristaltic activity and produces permeability changes in the intestinal mucosal membrane to electrolytes and water. More precisely, castor oil elevates the biosynthesis of prostaglandin [19-21] which results in irritation and inflammation of the intestinal mucosa to stimulate the motility and secretion [21-23]. Castor oil model, therefore, incorporates both secretory and motility diarrhea [24]. Several other mechanisms had been previously proposed to explain the diarrheal effect of castor oil which include inhibition of intestinal $\mathrm{Na}+\mathrm{K}+$ ATPase activity, thus reducing normal fluid absorption [24]. It is possible that the P. foetidus fractions were able to inhibit electrolyte permeability due to castor oil and prostaglandins release [25]. Suppression of the intestinal fluid accumulation 
by the extract might also suggest the inhibition of gastrointestinal function [26]. The above speculation was further supported by the inhibitory action of the extract on intestinal charcoal meal motility. However, it is well proved that castor oil produces diarrhea due to its most active component ricinoleic acid through a hypersecretory response $[18,22]$. Therefore, it can be assumed that the antidiarrheal action of the extract was mediated by an antisecretory mechanism and also by reducing gastrointestinal motility contributed by the phytochemical agents possessed by the plant extract. Phytochemical screening of the methanolic extract of Podocarpus neriifolius, Mangifera sylvatica and Ficus sagittata ensured the presence of carbohydrate, glycoside, alkaloids, tannins, flavonoids and steroids $[14,15]$. The inhibitory activity of flavonoids on intestinal motility in a dose related manner was earlier reported [27, 28]. Apart from this, previous studies have shown that antidysenteric and antidiarrheal properties of plants are due to tannins, alkaloids, saponins, flavonoids, sterol, triterpenes and reducing sugars [29]. These findings are consistent with the phytochemical existence of Podocarpus neriifolius, Mangifera sylvatica and Ficus sagittata. Therefore, the antidiarrheal activity of the methanolic extract of Podocarpus neriifolius, Mangifera sylvatica and Ficus sagittata may be attributed to the phytochemicals present in this plant and it is as well supported by literature for other plants [30, 31].

The use of plant-derived medicines for the treatment of diarrhea is a common practice in many folk medications. Many people in the developing countries still rely on the treatment system employing medicinal plants [32]. Relevantly, methanol extract of Podocarpus neriifolius, Mangifera sylvatica and Ficus sagittata used in our study were found to be significantly antidiarrheal in castor oil induced changes of gastrointestinal tract. However, Mangifera sylvatica displayed the highest inhibitory action in the antidiarrheal models. The above mentioned function needs to be clarified with the possible mechanism how the extract works for exerted effects so that the plant species can be used for antidiarrheal formulation.

\section{Conclusion}

The results of this investigation revealedn that Podocarpus neriifolius, Mangifera sylvatica and Ficus sagittata leaves extract possess significant antidiarrheal properties. Further research is needed to fractionate the methanol extract and isolate the molecule(s) responsible for the antidiarrheal activity observed.

\section{Acknowledgements}

Authors wish to thank Dr. Sheikh Bokhtear Uddin, Associate professor, Department of Botany, University of Chittagong for the taxonomical identification of the plants. Autors are also grateful to the authority International Islamic University Chittagong for the grant of this research work and providing laboratory facilities.

\section{References}

1. Shoba, F.G.; Thomas, M. Study of antidiarrheal activity of four medicinal plants in castor oil-induced diarrhea, J Ethnopharmacol, 2001, 76, 73-76. DOI: $10.1016 / \mathrm{S} 0378-8741(00) 00379-2$

2. Lakshminarayana shastry viswanatha, G.; Hanumanthappa, S.; Nandakumar, K.; Srinatha, R. Antidiarreal effect of fractions from stem bark of Thespesia populnea in rodents: Possible antimotility and antisecretory mechanisms, Asian pac J Trop med, 2011, 451-456.

3. Sayeed, M.A.; Kabir, M.F.; Alam, R.; Dhar, R.; Shill, L.K.; Karim, N.; Ullah, A. Effects of antidiarrheal and thrombolytic activities of methanol extract of cinnamomum cecidodaphne meissn. Barks, European Journal of Biomedical and Pharmaceutical Sciences, 2014, 1(2), 421-434.

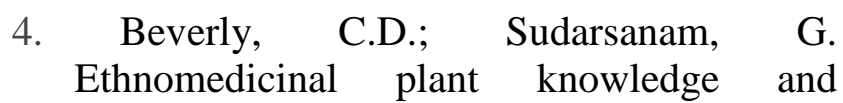


practice of people of Javadhu hills in Tamilnadu, Asian Pac J Trop Biomed, 2011, S79-S81

DOI: $10.1016 / \mathrm{S} 2221-$ 1691(11)60129-9

5. Maikere-Faniyo, R.; Van Puyvelde, L.; Mutwewingabo, A.; Habiyaremye, F.X. Study of Rwandese medicinal plants used in the treatment of diarrhea, J Ethonopharmacol, 1989, 26, 101-109. DOI: $10.1016 / 0378-8741(89) 90057-3$

6. Syder, J.D.; Merson, M.H. The magnitude of the global problems of acute diarrheal disease: A review of active surveillance data, Bull WHO, 1982, 60, 605-613.

7. Lutterodt, G.D. Inhibition of gastrointestinal release of acetylcholine by quercetin as a possible mode of action of Psidium guajava leaf extracts in the treatment of acute diarrhea disease, J Ethnopharmaco, 1989, 25, 235-247.

DOI: $10.1016 / 0378-$ 8741(89)90030-5

8. Park, K. Park's Text book of Preventive and Social Medicine, Jabalpur, India, M/S Banarsidas Bharat Publishers, Jabalpur, 2000; pp 172- 175.

9. FDA News Release. U.S. Food and Drug Administration, Dec, 31, 2012

10. Plant Resources of south-East Asia No. 5(2): Timber tress: Minor commercial timbers.

11. Podocarpus neriifolius D.Don in A.B. Lambert, A Description of the genus Pinus, edition 1, 1824, Vol. 2, 21.

12. Li-zhen, X.; Zhen, C.; Nan-jun, S. Studies on Chemical Compositions of Podocarpus neriifolius D. Don, Jour Integ Plan, 1993, 35(2), 138.

13. Shrestha, K. An antiproliferative norditerpene dilactone, Nagilactone C, from Podocarpuc neriifolius D. Don, Phytomed, 2001, 8(6), 489. DOI: $10.1078 / \mathrm{S} 0944-7113(04) 70071-9$

14. Zaman, R.; Parvez, M.; Jakaria, M.; Sayeed, M.A. In-Vitro Cytotoxic and Thrombolytic Potential of Methanolic Extract of Podocarpus neriifolius D. Don leaves, Int JourPharma Sci Res, 2015, 6(2), 273.
15. Zaman, R.; Parvez, M.; Jakaria, M.; Sayeed, M.A.; Islam, M. In vitro Clot Lysis Activity of Different Extracts of Mangifera sylvatica Roxb. Leaves, Research Journal of Medicinal Plant, 2015, 9(3), 135-140. DOI: 10.3923/rjmp. 2015.

16. http://tropical.theferns.info/ [http://tropical. theferns.info/viewtropical.php?id=Ficus+sagi ttata], Accessed on May 12, 2015.

17. Acute Oral toxicity - Acute Toxic Class Method, OECD Guidelines for the Testing of Chemicals, Section 4: Test No. 423, 2002.

18. Ammon, H.V.; Thomas, P.J.; Phillips, S.F. Effect of the oleic acid and ricinoleic acid net jejunal water and electrolyte movement, J Clin Invest, 1974, 53, 374-9. DOI: $10.1172 / \mathrm{JCI} 107569$

19. Awouters, F.; Niemegeers, C.J.E.; Lenaerts, F.M.; Janseen, P.A.J. Delay of castor oil diarrhea in rats; a new way to evaluate inhibitors of prostaglandin biosynthesis, J Pharmacol, 1998, 30, 41-5. DOI: $\underline{10.1111 / j .2042-7158.1978 . t b 13150 . x}$

20. Bruton, L.L. Agents affecting gastrointestinal water flux and motility digestant: and bile acids. In: A.G. Gillman, T.W. Rail, A.S. Nies and P. Taylor, Editors, Pharmacol. Basis of Therapeutics, 8th ed, vol.2, McGraw, New York, 1985; pp 914.

21. Galvez, J.; Zarzuelo, A.; Crespo, M.E. Antidiarrhoeic activity of Scleroarya birrea bark extract and its active tannin constituent in rats, Phytother Res, 1991, 5, 276-278. DOI: $10.1002 /$ ptr.2650050611

22. Gaginella, T.S.; Bass, P. Laxatives: an update on mechanism of action, Life Sci, 1978, 23, 1001-10. $\underline{3205(78) 90659-8}$

DOI: $10.1016 / 0024-$

23. Pierce, N.F.; Carpenter, C.C.J.; Elliot, H.Z.; Greenough, W.B. Effects of prostaglandins, theophylline and cholera exotoxin upon transmucosal water and electrolyte movement in canine jejunum, Gastroenterol, 1971, 60, 22-32.

24. Yegnanarayan, R.; Shrotri, M.D.D.S. Comparison of antidiarrhoeal activity of 
some drugs in experimental diarrhea, Indian J Pharmacol, 1982, 14, 293-299.

25. Adzu, B.; Amos, S.; Wambebe, C.; Gamaniel, K. Antinociceptive activity of Ziziphus spinachristi root bark extract, Fitoterapia, 2001, 72, 334-350. DOI:10.1016/S0367326X(00)00289-6.

26. Nwafor, P.A.; Okwuasaba, F.K.; Binda, L.G. Antidiarrhoeal and antiulcerogenic effects of methanolic extract of Asparagus pubescent root in rats, J Ethnopharmacol, 2000, 72, 421-427. DOI: $10.1016 / \mathrm{S} 0378-$ 8741(00)00261-0

27. Dicarlo, G.D.; Mascolo, N.; Izzo, A.A.; Capasso, F. Effect of querecetine on the gastrointestinal tract in rats and mice, Phytother Res, 1994, 8, 42-45. DOI: $10.1002 /$ ptr.2650080110

28. Meli, R.; Autore, G.; Dicarlo, G.; Capasso, F. Inhibitory action of querecetin on intestinal transit in mice, Phytother Res, 1990, 4, 201202. DOI: $10.1002 /$ ptr.2650040509

29. Longanga, O.A.; Vercruysse, A.; Foriers, A. Contribution to the ethnobotanical, phytochemical and pharmacological studies of traditionally used medicinal plants in the treatment of dysentery and diarrhoea in Lomela area, Democratic Republic of Congo (DRC). J Ethnopharmacol, 2000, 71, 411423. DOI: 10.1016/S0378-8741(00)00167-7

30. Dahiru, D.; Sini, J.M.; John-Africa, L. Antidiarrhoeal activity of Ziziphus mauritiana root extract in rodents, Afr J Biotechnol, 2006, 5, 941-945.

31. Boominathan, P.; Shukla, R.; Kumar, A.; Manna, D.; Negi, D.; Verma, P.K.; Chattopadhyay, D. Long term transcript accumulation during the development of dehydration adaptation in Cicer arietinum, Plant Physiology, 2004, 135, 1608-1620. DOI: $10.1104 / p p .104 .043141$

32. Ojewole, J.A.O. Evaluation of antidiarrheal, anti-inflammatory and antidiabetic properties of Sclerocarya birrea (A. Rich.) Hochst. stem bark aqueous extract in mice and rats, Phytotherapy Res, 2004,18, 601-608. DOI: $10.1002 /$ ptr.1503 